\title{
Population structure of the banana weevil, an introduced pest in the Canary Islands, studied by RAPD analysis
}

\author{
C. Magaña ${ }^{1}$, B. Beroiz ${ }^{1}$, P. Hernández-Crespo ${ }^{1}$, \\ M. Montes de $\mathrm{Oca}^{2}$, A. Carnero ${ }^{3}$, F. Ortego ${ }^{1}$ \\ and P. Castañera ${ }^{1 *}$
}

${ }^{1}$ Dpto. de Biología de Plantas, Centro de Investigaciones Biológicas, CSIC. Madrid, Spain: ${ }^{2}$ Escuela Técnica Superior de Ingenieria Agraria, U.L.L. La Laguna-Tenerife, Spain: ${ }^{3}$ Dpto. Protección Vegetal del I.C.I.A., Apdo. 60, 38200 La Laguna-Tenerife, Spain

\begin{abstract}
The banana weevil (BW), Cosmopolites sordidus (Coleoptera: Curculionidae), is one of the most important insect pests of bananas and plantains. The mobility and the origin of BW infestations at the Canary Islands (Tenerife, La Gomera and La Palma) have been analysed using Random Amplified Polymorphic DNA (RAPD) as molecular markers. Populations from Costa Rica, Colombia, Uganda and Madeira were also included for comparison. One hundred and fifteen reproducible bands from eight primers were obtained. The level of polymorphism in the populations from the Canary Islands $(40-62 \%)$ was in the range of those found in other populations. Nei's genetic distances, pair-wise fixation index $\left(F_{\mathrm{ST}}\right)$ values indicate that the closest populations are Tenerife populations among themselves (Nei's genetic distance $\left.=0.054-0.100 ; \quad F_{\mathrm{ST}}=0.091-0.157\right)$ and Costa Rica and Colombia populations (Nei's genetic distance $=0.049 ; F_{\mathrm{ST}}=0.113$ ). Our results indicate the existence of BW local biotypes with limited gene flow and affected by genetic drift. These results are compatible with a unique event of colonization at Tenerife; whereas, the outbreaks in La Gomera and La Palma may come from independent introductions. The Madeira population is phylogenetically and geographically closer to the Canary Islands populations, suggesting that it is the most likely source of the insects introduced in the Canary Islands.
\end{abstract}

Keywords: molecular markers, Cosmopolites sordidus, genetic structure, gene flow

\section{Introduction}

The banana weevil (BW), Cosmopolites sordidus (Germar, 1824) (Coleoptera: Curculionidae), is one of the most important insect pests of bananas and plantains (Musa spp.) worldwide (Ostmark, 1974; Rukazambuga et al., 1998). The larvae tunnels throughout the corm weaken the plant and provide entry for rot-promoting organisms, preventing crop

*Author for correspondence

Fax: + 34915360432

E-mail: castan@cib.csic.es establishment, causing yield reductions and shortening plantation life (Gold et al., 2001). At present, control strategies focus on cultural practices and the use of synthetic pesticides (Gold \& Messiaen, 2000).

The BW is believed to have originated in the IndoMalayan region, spreading to the entire world's major banana growing regions (Ostmark, 1974). The adults have functional wings, but flight is uncommon, the BW being relatively sedentary (Gold et al., 2001). Moreover, its narrow host range and low reproductive potential limits its dispersal capability (Gold et al., 2001). Thus, it is widely recognised that new infestations of this pest are mainly caused by infested planting material (Gold et al., 2001). Ochieng (2001) 


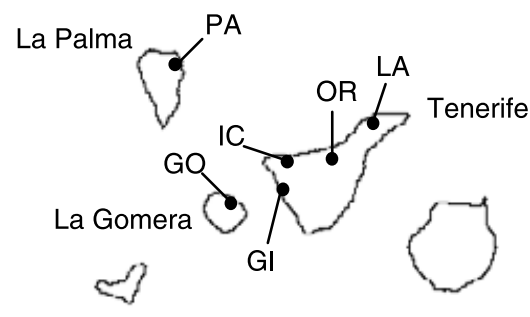

Fig. 1. Sampling sites of Cosmopolites sordidus collected in the Canary Islands. For population codes see table 1.

showed that considerable variation exists between BW populations from different parts of the world, suggesting the existence of discrete populations with limited gene flow and the likely evolution of local biotypes.

Banana is a traditional crop in the Canary Islands, where it is commercially grown on four of the Islands: Tenerife (4255 ha), La Palma (3261 ha), Gran Canaria (1936 ha) and La Gomera (199 ha) (http:/ / www.gobcan.es, data 2004). Banana weevil infestations were first reported at Gran Canaria in 1945 , but a rapid intervention resulted in the eradication of the pest at that time. A new focus was detected in Tenerife in 1986 that spread rapidly throughout this island and to the nearby islands of La Gomera (1997) and La Palma (2001) (Carnero et al., 2004). However, there is no information regarding the source of the weevils introduced in the Canary Islands. The estimation of genetic variation in populations is a key aspect of pest studies and provides information on their ecology. The extent of genetic variation between populations depends on several factors such as gene flow between populations and time since separation (Hartl, 1980). In this case, a detailed record of the time of infestation of C. sordidus across the banana growing areas in the Canary Islands is available, which will allow us to investigate the dispersion and origin of the BW in the Canary Islands and to compare the Canary Islands BW with populations from traditionally affected banana growing areas in other countries. Accordingly, we have analysed the genetic diversity of the populations present on the three islands (Tenerife, La Gomera and La Palma) and compared them with populations from Africa, Central America and South America, by using Random Amplified Polymorphic DNA (RAPD) as molecular markers (Welsh \& McClelland, 1990; Williams et al., 1990). RAPDs are sensitive enough to detect differences between individuals showing a close genetic relationship. The main advantage of this method is that it can be applied with few requirements for modelling, assumptions or analysis (Black IV, 1993). Moreover, this technique has been demonstrated to be useful in elucidating geographical origins and dispersal routes of insect pest populations, particularly curculionid weevils (Taberner et al., 1997; Bas et al., 2000; Scataglini et al., 2000; Kim \& Sappington, 2004).

\section{Materials and methods}

\section{Insects}

Banana weevil adults were collected from banana fields at six different locations in the Canary Islands (Spain), four along the coastal plain in the north and west of Tenerife, and two from the only localities where the pest has been detected in La Palma and La Gomera (fig. 1). Insects were collected using pseudostem traps, transferred to the laboratory and stored at $-20^{\circ} \mathrm{C}$. Adult weevils from banana fields in Madeira, Costa Rica and Uganda and a plantain field in Colombia, were preserved in ethanol $70 \%(\mathrm{v} / \mathrm{v})$ before DNA extraction. All individuals were collected from a single site at each location. Sampling locations, sample sizes and identification codes are listed in table 1.

\section{DNA extraction}

Genomic DNA was isolated from cleaned legs of single adults following a modified method of Aubert \& Lightner (2000). Legs were homogenized in $400 \mu \mathrm{l}$ of an extraction buffer $(0.1 \mathrm{~m} \mathrm{NaCl}, 0.01 \mathrm{~m}$ EDTA, $\mathrm{pH}$ 8). The homogenate was treated with proteinase $\mathrm{K}\left(1 \mathrm{mg} \mathrm{ml}^{-1}\right)$ and SDS $(1 \%)$ and incubated at $37^{\circ} \mathrm{C}$ overnight. Then, $\mathrm{NaCl}$ and $\mathrm{CTAB}$ (Cetyltrimethylammonium Bromide) were added to a final concentration of $0.70 \mathrm{M}$ and $1 \%$, respectively, keeping the solution at $62^{\circ} \mathrm{C}$ for $10 \mathrm{~min}$. Genomic DNA was passed consecutively through 1 volume of phenol, phenol:chloroform : isoamilic alcohol $(25: 24: 1)$ and chloroform : isoamilic alcohol $(24: 1)$. Water was added to decrease $\mathrm{NaCl}$ concentration to $0.5 \mathrm{M}$, and DNA was pelleted adding one volume of isopropanol and centrifuging. The pellet was washed with $70 \%$ ethanol, resuspended in $100 \mu \mathrm{l}$ of TE $(10 \mathrm{~mm}$ Tris $-\mathrm{HCl}$, $1 \mathrm{~mm}$ EDTA, pH 8), and treated with RNAase $\left(0.1 \mu \mathrm{g} \mu \mathrm{l}^{-1}\right)$. DNA concentration was estimated in a spectrophotometer.

\section{PCR amplification}

A total of eight Operon decamers from KIT-E (Operon Technologies), producing clearly discernable and reproducible bands, were selected for the analysis (OPE02, OPE04, OPE06, OPE08, OPE09, OPE11, OPE13 and OPE19) (table 2). Each $25 \mu \mathrm{l}$ reaction contained $100 \mathrm{ng}$ of genomic DNA, $1 \times$ stoffel buffer, $3 \mathrm{~mm} \mathrm{MgCl} 2,0.4 \mu \mathrm{M}$ primer, $200 \mu \mathrm{M} \mathrm{dNTP}$ and two units of Stoffel Fragment Amplitaq DNA Polymerase (Applied Biosystems). PCR amplifications were performed in a GeneAmp PCR System 2400 (Applied Biosystems) programmed for an initial hold of $3 \mathrm{~min}$ at $94^{\circ} \mathrm{C}$, followed by 35 cycles of amplification $\left(30 \mathrm{~s}\right.$ at $94^{\circ} \mathrm{C}, 1 \mathrm{~min}$ at $40^{\circ} \mathrm{C}$ and $2 \mathrm{~min}$ at $72^{\circ} \mathrm{C}$ with an autoextension of $2 \mathrm{~s}$ ) and ended with a hold of $6 \mathrm{~min}$ at $72^{\circ} \mathrm{C}$. Negative controls without DNA template were included in each reaction.

Amplification products were resolved in 2\% agarose gels with TAE buffer ( $40 \mathrm{~mm}$ Tris-Acetate, $1 \mathrm{~mm}$ EDTA, $\mathrm{pH}$ 8.0). The gels were stained with ethidium bromide and photographed under UV light with Polaroid film 667. A $100 \mathrm{bp}$ DNA ladder (Roche) was used as a standard molecular weight marker. Reproducibility of RAPD patterns was evaluated by replicating the PCR reaction on all specimens from collections from the Canary Islands and on at least four specimens from the other localities, with all primers.

\section{Data analysis}

Four assumptions are taken in the statistical analysis: (i) bands of different molecular weight amplified from the same or different individuals correspond to different alleles; (ii) bands of equal molecular weight amplified by the same primer correspond to homologous alleles; (iii) alleles follow Mendelian inheritance; and (iv) alleles segregate as 
Table 1. Sampling locations, sizes and identification codes for Cosmopolites sordidus collections.

\begin{tabular}{lllc}
\hline Region & \multicolumn{1}{c}{ Locality } & Code & $\begin{array}{c}\text { Sample } \\
\text { size }\end{array}$ \\
\hline Tenerife, Canary Islands, Spain & Guía de Isora & GI & 31 \\
& Icod de los Vinos & IC & 30 \\
& La Orotava & OR & 22 \\
& La Laguna & LA & 18 \\
La Gomera, Canary Islands, Spain & Hermigua, & GO & 20 \\
La Palma, Canary Islands, Spain & San Andrés y Sauces & PA & 20 \\
Costa Rica & Cantón de Siquirres, Provincia & CR & 20 \\
Colombia & de Limón & CO & 20 \\
Madeira, Portugal & Municipio de Armenia, Quindío & MA & 20 \\
Uganda & Lugar de Baixo, Ponta do Sol & UG & 20 \\
& Kankamba parish, Kisekka & & \\
\hline
\end{tabular}

Table 2. Sequence of the decamer primers used in this study and number of amplification products.

\begin{tabular}{llc}
\hline Primer & Sequence $\left(5^{\prime}-3^{\prime}\right)$ & $\begin{array}{c}\text { No. of } \\
\text { amplification } \\
\text { products }\end{array}$ \\
\hline E-02 & GGTGCGGGAA & 9 \\
E-04 & GTGACATGCC & 13 \\
E-06 & AAGACCCCTC & 13 \\
E-08 & TCACCACGGT & 14 \\
E-09 & CTTCACCCGA & 11 \\
E-11 & GAGTCTCAGG & 15 \\
E-13 & CCCGATTCGG & 18 \\
E-19 & ACGGCGTATG & 22 \\
Total & & 115 \\
\hline
\end{tabular}

dominant markers. Only reproducible amplification products in the intermediate molecular weight range (1000$300 \mathrm{bp}$ ) were used to create a binary presence/absence matrix dataset with all individuals. Nei (1972) genetic distances among populations were calculated using the RAPDdist programme (RAPD-PCR Software Package). Bootstrapping over loci was also performed with RAPDdist (1000 permutations) to produce a distance matrix for each pseudo-replicated dataset. A dendrogram was constructed by unweighted pair-group UPGMA cluster analysis (Sneath \& Sokal, 1973) using the programme PHYLIP v. 3.5c (Felsenstein, 1993).

Genetic subdivision among populations was estimated from the $F_{\mathrm{ST}}$ coefficient (Wright, 1951) and $\theta$ indices (Weir \& Cockerham, 1984; Lynch \& Milligan, 1994). Both analyses were performed using the RAPDFST programme. The genetic structure of the populations was examined by analysis of molecular variance (AMOVA, Excoffier et al., 1992) using the ARLEQUIN 2.000 package (Schneider et al., 2000). AMOVA was used to assess the partitioning of the genetic variation within populations, among populations within regions and among regions. The level of significance for variance component estimates was determined by nonparametric permutation procedures using 1000 permutations.

\section{Results}

Only primers yielding consistent gel patterns from gel to gel and from individual to individual were used.

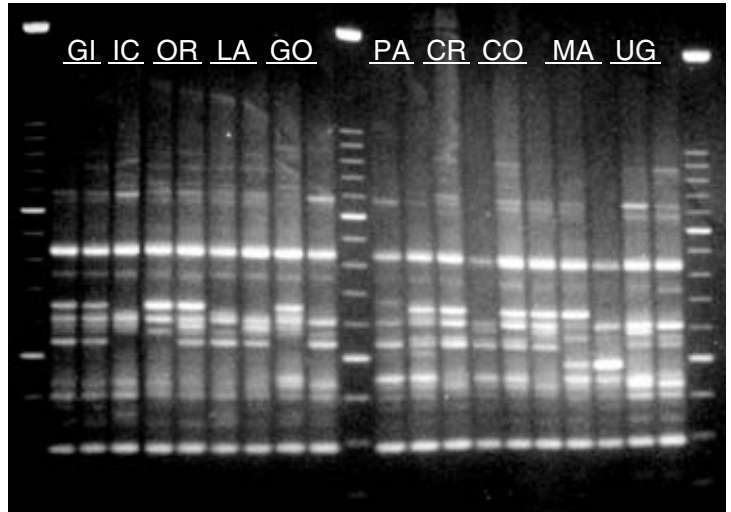

Fig. 2. Representative RAPD profile obtained after amplification of $C$. sordidus DNA from individuals of different populations using OPE06 primer. For population codes see table 1.

The primers revealed a total of 115 reproducible bands (9-22 bands per primer) in 221 individuals from three of the Canary Islands (Tenerife, La Gomera, La Palma, see fig. 1), the nearby Madeira Island, and the distant continental countries Uganda (Africa), Colombia (South America) and Costa Rica (Central America) (table 1). Different bands were considered as different anonymous loci in the analysis. Overall, 96 bands were found to be polymorphic at the $95 \%$ level. Unique population-specific bands were not observed. However, one band of approximately $495 \mathrm{bp}$, obtained with primer OPE04, was present in $100 \%$ of the individuals from the Canary Islands and Madeira, but was absent in individuals from Colombia and Costa Rica, and present at a low percentage (10\%) in individuals from Uganda. Indeed, three bands obtained with OPE19 (960 bp, $870 \mathrm{bp}$ and $750 \mathrm{bp}$ ), two bands obtained with OPE02 (800 bp and 620 bp) and one band obtained with OPE13 $(810 \mathrm{bp})$ were present in all individuals except those from Uganda. Furthermore, three bands obtained with OPE04 (805 bp, $780 \mathrm{bp}$ and $495 \mathrm{bp}$ ) and one band obtained with OPE09 (530 bp), OPE11 (560 bp) and OPE13 (750 bp) were not present in individuals from Costa Rica. A representative RAPD profile obtained after amplification using OPE06 primer is shown in fig. 2.

The population from Costa Rica exhibited relatively low levels of polymorphism (39\%) when compared with 


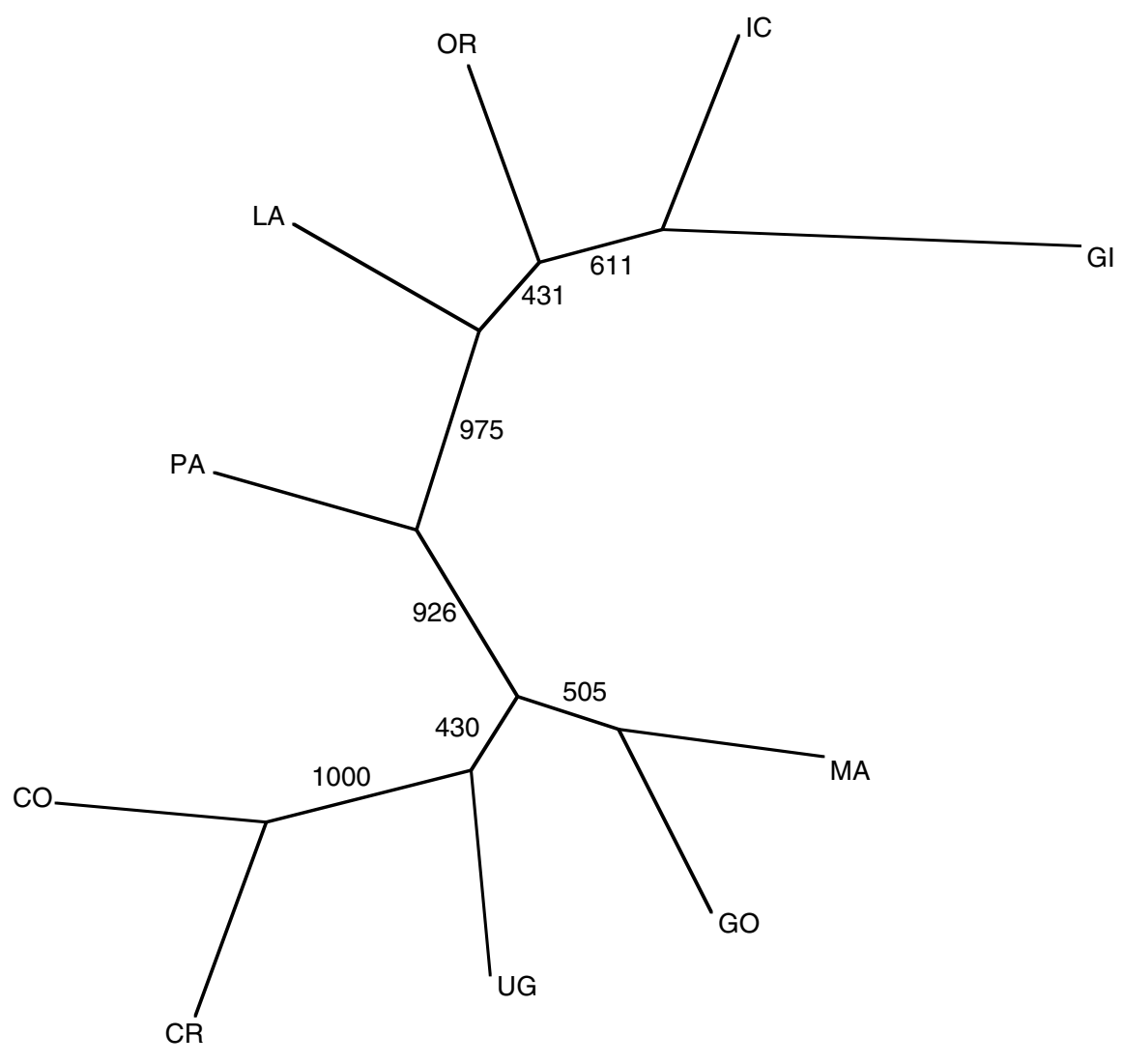

100

Fig. 3. Unrooted UPGMA tree depicting the genetic relationships among the ten Cosmopolites sordidus populations analysed, based on Nei's genetic distances. Numbers at branch points are bootstrap values representing the number of times the branching was supported out of 1000 replications. For population codes see table 1.

polymorphism values shown in populations from Colombia (61\%), Madeira (72\%) and Uganda (51\%). Among the Canary Islands, the population from La Palma showed higher levels of polymorphism (62\%) than those of La Gomera and Tenerife, which ranged between 40 and $55 \%$.

Nei's distance matrix, using Lynch and Milligan's (1994) correction, was analysed to obtain a phylogenetic tree by the UPGMA method (fig. 3). Four main clusters are differentiated on the tree: (i) the four populations from Tenerife (GI, IC, OR and LA); (ii) the population from La Palma (LA); (iii) the populations from La Gomera (GO), Madeira (MA) and Uganda (UG); and (iv) the populations from Colombia and Costa Rica. Among the populations from Tenerife, the populations from the northwest (GI and IC) and northeast (OR and LA) are differentiated on the tree showing a moderate bootstrap value. Genetic distances among populations are shown in table 3. The lowest genetic distance values (table 3 , above diagonal) correspond to the comparison between Tenerife populations (0.054-0.100) and between Colombia and Costa Rica populations (0.049). Comparing populations from the three Canary Islands, the lowest values correspond to the paired comparisons between La Palma and Tenerife populations (0.111-0.158), and the highest distances correspond to the paired comparison between La
Gomera and the others (0.153-0.221). Comparing Canary Island populations with the rest of the populations studied, Nei's genetic distances range from 0.158 (Madeira vs Gomera) to 0.290 (Gomera vs Uganda), which was the maximum value among all the populations studied.

Pair-wise fixation indices $\left(F_{\mathrm{ST}}\right)$ for all populations are shown in table 3. All paired comparisons revealed significant genetic differentiation, $F_{\mathrm{ST}}$ values ranging from 0.091 (west Tenerife populations, GI vs IC) to 0.390 (Costa Rica, CR, vs La Palma Island, PA). In concordance with Nei's genetic distance values, the lowest $F_{\mathrm{ST}}$ values corresponded to the comparison among Tenerife Island populations (from 0.091 to 0.157$)$ or Costa Rica and Colombia populations (0.113). These values were higher in the paired comparison of populations from the three Canary Islands, from 0.161 (PA vs IC) to 0.269 (LA vs GO), or in the paired comparison of Canary Island populations with other populations studied, from 0.209 (OR vs MA) to 0.390 (LA vs CR). Estimates of $F_{\mathrm{ST}}$ coefficients (Wright, 1951) or $\theta$ indices (Weir and Cockerham, 1984; Lynch and Milligan, 1994) gave similar results (data not shown).

Hierarchical analysis of the genetic structure was performed considering the populations from Tenerife as one region (Tenerife) and populations from Costa Rica 
Table 3. Above the diagonal, Nei's genetic distances among populations calculated from RAPD analysis. Below the diagonal, pair-wise $F_{\mathrm{ST}}$ and standard error $( \pm S E)$ (Wright, 1951). See codes for samples location in table 1.

\begin{tabular}{|c|c|c|c|c|c|c|c|c|c|c|}
\hline & \multicolumn{6}{|c|}{ Canary Islands } & \multirow{3}{*}{$\frac{\text { Costa Rica }}{\mathrm{CR}}$} & \multirow{3}{*}{$\frac{\text { Colombia }}{\mathrm{C} 0}$} & \multirow{3}{*}{$\frac{\text { Madeira }}{\text { MA }}$} & \multirow{3}{*}{$\frac{\text { Uganda }}{\text { UG }}$} \\
\hline & \multicolumn{2}{|c|}{ West Tenerife } & \multicolumn{2}{|c|}{ East Tenerife } & \multirow{2}{*}{$\frac{\text { La Gomera }}{\mathrm{GO}}$} & \multirow{2}{*}{$\frac{\text { La Palma }}{\text { PA }}$} & & & & \\
\hline & GI & $\mathrm{IC}$ & OR & LA & & & & & & \\
\hline GI & & 0.054 & 0.062 & 0.061 & 0.198 & 0.158 & 0.277 & 0.270 & 0.221 & 0.280 \\
\hline $\mathrm{IC}$ & $0.091 \pm 0.017$ & & 0.065 & 0.064 & 0.187 & 0.111 & 0.270 & 0.255 & 0.206 & 0.263 \\
\hline OR & $0.106 \pm 0.016$ & $0.113 \pm 0.015$ & & 0.100 & 0.153 & 0.123 & 0.252 & 0.234 & 0.175 & 0.250 \\
\hline LA & $0.105 \pm 0.020$ & $0.106 \pm 0.017$ & $0.157 \pm 0.026$ & & 0.203 & 0.155 & 0.279 & 0.275 & 0.207 & 0.266 \\
\hline $\mathrm{GO}$ & $0.245 \pm 0.033$ & $0.231 \pm 0.036$ & $0.204 \pm 0.032$ & $0.269 \pm 0.040$ & & 0.221 & 0.202 & 0.196 & 0.158 & 0.290 \\
\hline PA & $0.210 \pm 0.029$ & $0.161 \pm 0.027$ & $0.168 \pm 0.033$ & $0.212 \pm 0.038$ & $0.267 \pm 0.040$ & & 0.223 & 0.214 & 0.199 & 0.206 \\
\hline CR & $0.348 \pm 0.048$ & $0.335 \pm 0.056$ & $0.322 \pm 0.048$ & $0.390 \pm 0.056$ & $0.301 \pm 0.046$ & $0.235 \pm 0.015$ & & 0.049 & 0.244 & 0.241 \\
\hline $\mathrm{CO}$ & $0.313 \pm 0.043$ & $0.293 \pm 0.041$ & $0.279 \pm 0.044$ & $0.338 \pm 0.051$ & $0.262 \pm 0.040$ & $0.260 \pm 0.025$ & $0.113 \pm 0.012$ & & 0.194 & 0.171 \\
\hline MA & $0.237 \pm 0.033$ & $0.228 \pm 0.035$ & $0.209 \pm 0.038$ & $0.240 \pm 0.043$ & $0.206 \pm 0.033$ & $0.220 \pm 0.022$ & $0.230 \pm 0.010$ & $0.275 \pm 0.010$ & & 0.151 \\
\hline UG & $0.330 \pm 0.046$ & $0.302 \pm 0.048$ & $0.312 \pm 0.049$ & $0.340 \pm 0.054$ & $0.352 \pm 0.047$ & $0.281 \pm 0.011$ & $0.323 \pm 0.035$ & $0.274 \pm 0.042$ & $0.219 \pm 0.032$ & \\
\hline
\end{tabular}

Table 4. Analysis of molecular variance (AMOVA) performed on different groupings of Cosmopolites sordidus populations.

\begin{tabular}{|c|c|c|c|c|c|}
\hline Source of variance & $\mathrm{df}$ & $\begin{array}{c}\text { Sum of squared } \\
\text { deviation }\end{array}$ & $\begin{array}{l}\text { Variance } \\
\text { component }\end{array}$ & $\begin{array}{l}\text { Percentage } \\
\text { of variance }\end{array}$ & $P$ \\
\hline \multicolumn{6}{|l|}{$\begin{array}{l}\text { Regions (Tenerife }{ }^{1}, \text { La Palma, La Gomera, } \\
\text { Madeira, America }{ }^{2} \text { and Uganda) }\end{array}$} \\
\hline Among populations within regions & 4 & 265.44 & 2.43 & 13.6 & $<0.001$ \\
\hline Among individuals within populations & 211 & 1853.77 & 8.79 & 49.1 & $<0.001$ \\
\hline \multicolumn{6}{|l|}{ Regions (Islands ${ }^{3}$, America and Uganda) } \\
\hline Among individuals within populations & 211 & 1853.77 & 8.79 & 44.7 & $<0.001$ \\
\hline
\end{tabular}

${ }^{1}$ The four populations from Tenerife are grouped as the Tenerife region; ${ }^{2}$ populations from Costa Rica and Colombia are grouped as the American region; ${ }^{3}$ all populations from the Canary Islands and Madeira are grouped as the Island region.

and Colombia as another region (America) (table 4). In the AMOVA analysis, the higher percentage of variance corresponds to the genetic variation among individuals within populations $(49.1 \%)$. The percentage of variance corresponding to populations within regions (13.6\%) was lower than that corresponding to regions (37.3\%). A similar partition of the variance was obtained if the populations from the Canary Islands were grouped with Madeira in the Islands region (table 4).

\section{Discussion}

The BW recently has been introduced and established on the Canary Islands. As a result, a relatively low level of genetic variation caused by founder effects was expected (Szalanski, 1999; Roehrdanz, 2001; Kim \& Sappington, 2004). However, the levels of polymorphism in the populations from the Canary Islands (40-62\%) were in the range of those found in the populations from Colombia, Costa Rica, Madeira and Uganda, where BW has been established for a longer time (Gold et al., 2001; Nuno \& Ribeiro, 2002). In spite of the polymorphism detected, within-population variation is relatively low, as shown in the AMOVA analysis (table 4). These data are indicative of the existence of genetic drift that is most probably maintained by limited gene flow. Thus, the island isolation and the restricted mobility and dispersal of BW individuals, which are monophagous and live underground in small areas the major part of their lives (Gold et al., 2001), may favour the existence of BW local biotypes, as already suggested in a previous related study (Ochieng, 2001).

Interestingly, the phylogeny obtained can be easily related to the known history and pattern distribution of C. sordidus in the Canary Islands. The first outbreak was detected at Icod de los Vinos (IC) in the northwest of Tenerife in 1986. Thereafter, new outbreaks occurred on the northeast coast at La Orotava (OR) in 1990 and La Laguna (LA) in 1992 and on the western coast at Guía de Isora (GI) in 1994. Outbreaks at the nearby islands of La Gomera and La Palma were not reported until 1997 and 2001, respectively (Carnero et al., 2004). The individuals collected at the first focus at Icod de los Vinos (Tenerife) are the only ones that appear dispersed among clusters of other Tenerife populations on the tree obtained from Jackard's similarity coefficients (data not shown). These results are compatible with a unique event of colonization of BW at Icod de los Vinos (Tenerife), followed by its spreading to the surrounding banana growing areas, as reported for the weevil, Aubeonymus mariaefranciscae, on sugar beet crops in southern Spain (Taberner et al., 1997). The populations from La Palma and La Gomera are grouped in separate clusters on the UPGMA dendrogram. Moreover, Nei's genetic distances and $F_{\mathrm{ST}}$ values estimated for the paired comparison of populations from different islands, in relation to other values estimated for other paired comparisons, reveal that populations from different islands are genetically distant (table 3). All together, these data suggest independent events of colonisation at each Island, although it also could be explained by the existence of genetic drift, as mentioned above. 
Our data cannot explain unambiguously the geographical origin of the BW introduced in the Canary Islands, but indicate that these populations are more closely related to the Madeira population than to those from Colombia, Costa Rica or Uganda. This is supported by Nei's genetic distances and pair-wise fixation indexes (table 3). Thus, the mean and range (in parenthesis) of Nei's genetic distance values for the paired comparisons of the Canary Islands populations vs Madeira is $0.194(0.158-0.221)$, whilst it is $0.259(0.206-0.290)$, $0.241(0.196-0.275)$ and $0.251(0.202-0.279)$ for the Canary Island populations vs Uganda, Colombia and Costa Rica, respectively. Similarly, $F_{\mathrm{ST}}$ values range from 0.206 to 0.240 for the Canary Islands vs Madeira, whilst it ranges from 0.235 to 0.390 for the Canary Islands vs the other populations. Indeed, as mentioned before, one band of $495 \mathrm{bp}$ obtained with primer OPE04 was present in $100 \%$ of the individuals from the Canary Islands and Madeira, but absent or present at low frequencies in other populations analysed. Historical data support the hypothesis that BW might come from Madeira, since the first records of BW infestations in Madeira date back to the 19th century (Nuno \& Ribeiro, 2002). Nevertheless, further studies would be needed to establish precisely the origin of BW infestation.

\section{Acknowledgements}

This work was supported by INIA (grant RTA 02-100C3-2). We are grateful to Drs Clifford S. Gold (Uganda), Antonio M.F. Aguiar (Madeira), Consuelo Castrillon (Carpoica-Manizales, Colombia) and Douglas Cubillo (Costa Rica) for providing adults of BW. Thanks also are due to ASPROCAN and COPLACA, for technical assistance in field sampling of the populations from the Canary Islands.

\section{References}

Aubert, H. \& Lightner, D.V. (2000) Identification of genetic populations of the Pacific blue shrimp Penaeus stylirostris of the Gulf of California, Mexico. Marine Biology 137, 875-885.

Bas, B., Dalkilic, Z., Peever, T.L., Nigg, H.N., Simpson, S.E., Gmitter, F.G. \& Adair, R.C. (2000) Genetic relationships among Florida Diaprepes abbreviatus (Coleoptera: Curculionidae) populations. Annals of the Entomological Society of America 93, 459-467.

Black IV, W.C. (1993) PCR with arbitrary primers: approach with care. Insect Molecular Biology 2, 1-5.

Carnero, A., Montesdeoca, M., Magaña, C., Padilla, A., Herrera, R., Casañas, N., Ortego, F., Hernández-Crespo, P., Lobo, G., López-Llorca, L., García del Pino, F. \& Castañera, P. (2004) Pest status of Cosmopolites sordidus (Germar) (Coleoptera: Curculionidae) in the Canary Islands. XXII International Congress of Entomology, Brisbane, 15-20 August 2004, Brisbane, Australia.

Excoffier, L.L., Smouse, P.P.E. \& Quattro, J.J.M. (1992) Analysis of molecular variance inferred from metric distances among DNA haplotypes: application to human mitochondrial DNA restriction data. Genetics 131, 479-491.

Felsenstein, J. (1993) PHYLIP (Phylogeny Inference Package) version 3.5c. Distributed by the author, Department of Genetics, University of Washington, Seattle.

Gold, C.S. \& Messiaen, S. (2000) The banana weevil Cosmopolites sordidus. MusaPest INIBAP Fact Sheet No. 4.
Gold, C.S., Pena, J.E. \& Karamura, E.B. (2001) Biology and integrated pest management for the banana weevil Cosmopolites sordidus (Germar) (Coleoptera: Curculionidae). Integrated Pest Management Reviews 6, 79-155.

Hartl, D.L. (1980) Principles of Population Genetics. 488 pp. Sunderland, MA, Sinauer Associates.

Kim, K.S. \& Sappington, T.W. (2004) Genetic structuring of boll weevil populations in the US based on RAPD markers. Insect Molecular Biology 13, 293-303.

Lynch, M. \& Milligan, B.G. (1994) Analysis of population genetic structure with RAPD markers. Molecular Ecology 3, 91-99.

Nei, M. (1972) Genetic distance between populations. The American Naturalist 106, 283-292.

Nuno, L. \& Ribeiro, V.P. (2002) Cosmopolites sordidus in the autonomous region of Madeira. Infomusa 11, 10.

Ochieng, V.O. (2001) Genetic biodiversity in banana weevil Cosmopolites sordidus populations in banana growing regions of the world. $139 \mathrm{pp}$. PhD thesis, University of Nairobi, Kenya.

Ostmark, H.E. (1974) Economic insect pests of bananas. Annual Review of Entomology 19, 161-176.

Roehrdanz, R.L. (2001) Genetic differentiation of Southeastern Boll Weevil and Thurberia Weevil populations of Anthonomus grandis (Coleoptera: Curculionidae) using mitochondrial DNA. Annals of the Entomological Society of America 94, 928-935.

Rukazambuga, N.D.T.M., Gold, C.S. \& Gowen, S.R. (1998) Yield loss in East African highland banana (Musa spp., AAA-EA group) caused by the banana weevil, Cosmopolites sordidus Germar. Crop Protection 17, 581-589.

Scataglini, M.A., Confalonieri, V.A. \& Lanteri, A.A. (2000) Dispersal of the cotton boll weevil (Coleoptera: Curculionidae) in South America: evidence of RAPD analysis. Genetica 108, 127-136.

Schneider, S., Roessli, D. \& Excoffier, L. (2000) Arlequin ver 2.000: A software for population genetics and data analysis. Genetics and Biometry Laboratory, University of Geneva, Geneva, Switzerland.

Sneath, P.H.A. \& Sokal, R.R. (1973) Numerical Taxonomy: The Principles and Practice of Numerical Classification. 573 pp. San Francisco, CA, W.H. Freeman \& Co.

Szalanski, A.L. (1999) Genetic variation in geographical populations of western and Mexican corn rootworm. Insect Molecular Biology 8, 519-525.

Taberner, A., Dopazo, J. \& Castanera, P. (1997) Genetic characterization of populations of a de novo arisen sugar beet pest, Aubeonymus mariaefranciscae (Coleoptera, Curculionidae), by RAPD analysis. Journal of Molecular Evolution 45, 24-31.

Weir, B.S. \& Cockerham, C.C. (1984) Estimating F-statistics for the analysis of population structure. Evolution 38, 1358-1370.

Welsh, J. \& McClelland, M. (1990) Fingerprinting genomes using PCR with arbitrary primers. Nucleic Acids Research 18, 7213-7218.

Williams, J.G.K., Kubelik, A.R., Livak, K.J., Rafalski, J.A. \& Tingey, S.V. (1990) DNA polymorphisms amplified by arbitrary primers are useful as genetic markers. Nucleic Acids Research 18, 6531-6535.

Wright, S. (1951) The genetical structure of populations. Annals of Eugenics 15, 323-354.

(Accepted 22 February 2007)

(C) 2007 Cambridge University Press 